\title{
Pendekatan Inquiry Model Drill and Practice Berbasis Aplikasi Moodle Berbantuan Video Youtube untuk Meningkatkan Aktivitas dan Hasil Belajar Peserta Didik pada Materi Limit Fungsi
}

\author{
Wachid Nugroho \\ SMK Negeri 2 Salatiga \\ wachidnugroho1979@gmail.com
}

Abstrak: Pembelajaran konvensional dengan metode ceramah cenderung membosankan dan belum optimal meningkatkan aktivitas dan hasil belajar peserta didik. Penelitian ini bertujuan untuk mendeskripsikan penerapan pendekatan inquiry model drill and practice berbasis aplikasi moodle berbantuan video youtube pada materi limit fungsi pada peserta didik kelas XII Arsitek SMK Negeri 2 Salatiga dalam upaya peningkatan aktivitas dan hasil belajar. Penelitian ini merupakan penelitian tindakan kelas dengan dua siklus yang mengikuti tahapan perencanaan, pelaksanaan, pengamatan dan refleksi. Data dikumpulkan melalui: 1) pengisian angket mengenai aktivitas peserta didik; 2) pengamatan peneliti terhadap aktivitas peserta didik; dan 3) tes tertulis online di setiap akhir siklus melalui aplikasi moodle. Data angket, lembar pengamatan, dan penilaian belajar dianalisis mengggunakan deskripsi komparatif secara kuantitatif dan kualitatif untuk memperoleh hasil peningkatan aktivititas dan hasil belajar peserta didik. Hasil penelitian menunjukkan peningkatan kategori aktif peserta didik sebesar $8,83 \%$ dari capaian $79,41 \%$ pada siklus 1 menjadi $88,24 \%$ pada siklus 2 . Sedangkan nilai rerata kelas menunjukkan kenaikan sebesar 62,90 dari perolehan 850,00 pada siklus 1 meningkat menjadi 912,90 pada siklus 2. Ketuntasan kelas pada siklus 1 mencapai $67,65 \%$ meningkat 23,53\% menjadi 91,18\% pada siklus 2 . Berdasarkan hasil penelitian tersebut penerapan pendekatan inquiry model drill and practice berbasis aplikasi moodle berbantuan video youtube dapat meningkatkan aktivitas dan hasil belajar peserta didik pada materi limit fungsi aljabar. Para peneliti di bidang pendidikan dapat melakukan penelitian lanjutan dengan menerapkan berbagai pendekatan, strategi, model, metode, teknik, dan media yang relevan dengan kebaruan kurikulum terutama di masa pembelajaran jarak jauh untuk meningkatkan motivasi, peran serta, aktivitas, dan hasil belajar peserta didik.

Kata Kunci: Pendekatan Inquiry, Model Drill and Practice, Aplikasi Moodle, Video Youtube, Limit Fungsi, Aktivitas dan Hasil Belajar.

\section{Pendahuluan}

Beberapa permasalahan yang dihadapi guru dalam pembelajaran tatap muka apalagi pembelajaran jarak jauh (PJJ) pada materi limit fungsi aljabar adalah partisipasi aktif peserta didik dalam proses pembelajaran masih rendah. Kedua, masih sedikit peserta didik yang bisa mencapai target KKM pada penilaian harian di akhir materi yang telah disampaikan, padahal menjadi materi prasyarat khususnya lingkup kalkulus (turunan dan integral). Kesulitan lain yang dihadapi, subjek tidak dapat mengingat nama secara teknis, tidak dapat menyatakan arti istilah yang mewakili konsep tertentu, dan karena seringnya terjadi kesalahan operasi untuk menyelesaikan masalah limit, maka sulit untuk menerapkan prinsip-prinsip perhitungan pada materi limit fungsi.(Robiah, 2020).

Inovasi dan kreativitas guru diperlukan untuk menampilkan model pembelajaran interaktif yang menarik, menyenangkan, serta meningkatkan aktivitas belajar siswa, terutama kegiatan pembelajaran yang sesuai dengan model pembelajaran jarak jauh. Model pembelajaran discovery learning dapat meningkatkan hasil belajar siswa pada materi limit fungsi, ketuntasan klasikal siswa meningkat sebesar $58,82 \%$, kemudian menjadi $88,24 \%$ pada siklus II. (Sukma \& Supriyono, 2019). Peneliti lain (Butar-Butar, 2018) menyimpulkan terdapat peningkatan hasil belajar dengan menerapkan model problem based learning (PBL) pada bahasan limit fungsi. 
Sementara penggunaan pendekatan inquiry pernah diteliti (Agus, 2018) bahwa hasil dan motivasi belajar peserta didik pada materi limit fungsi yang menggunakan metode pembelajaran inquiry berbantuan maple lebih baik daripada yang menggunakan metode konvensional.

Untuk mengoptimalkan capaian kemampuan dari perspektif student-centered learning maka diperlukan model pembelajaran yang dapat memberikan kesempatan terbesar kepada siswa. Model latihan dan praktik merupakan salah satu alternatif pembelajaran yang tepat untuk materi limit fungsi. Penelitian yang dilakukan di kelas XI IPA 5 SMAN 7 Surakarta menyimpulkan bahwa metode pembelajaran drill and practice berbantuan modul dapat meningkatkan aktivitas dan prestasi belajar siswa (S. Nugroho et al., 2014). Sementara itu penelitian lain yang serupa menghasilkan kesimpulan bahwa metode latihan (drill and practice) dapat meningkatkan hasil belajar siswa pada materi limit fungsi di kelas XI IPA SMA Alkhairat Kalukubula (Wahyuni, Anggraini, 2016). Kemudian, metode drill dan resitasi melejitkan prestasi belajar siswa dengan kenaikan hasil belajar pada siklus I (65\%), siklus II (75\%), siklus III (95\%) (Sianturi, 2018).

Pembelajaran jarak jauh membutuhkan media dan sarana belajar yang efektif. Aplikasi moodle merupakan perangkat yang efektif dalam menyediakan fasilitasi pembelajaran online. Dari analisis hasil penelitian diperoleh simpulan, terdapat perbedaan rata-rata hasil belajar antara siswa yang pembelajarannya menggunakan aplikasi moodle dengan siswa yang pembelajarannya melalui media bantu powerpoint (Muin et al., 2012). Hasil belajar siswa dengan aplikasi moodle lebih tinggi daripada siswa yang pembelajarannya menggunakan media powerpoint. Beberapa penelitian merekomendasikan penggunaan e-learning berbasis aplikasi moodle yang berhasil. Pertama, pengembangan e-modul berbasis geogebra dengan dukungan website moodle (Rifa'i \& Nisa, 2019), kedua, elearning dengan moodle yang dipadukan dengan software matematika geogebra (Fahmi, et al., 2017), dan yang ketiga pembelajaran limit fungsi berbasis android dengan aplikasi math expert (Fitria Khasanah, 2019).

Agar peserta didik dapat belajar mandiri secara terbimbing dalam bertanya dan berdiskusi, melakukan penyelidikan, dan memahami konsep limit fungsi, diperlukan stimulus dalam mengawali pembelajaran. Salah satu alternatif media yang dapat memberikan rangsangan dan orientasi awal pembelajaran adalah video youtube. Penelitian (K. U. Z. Nugroho et al., 2019) mengenai efektivitas media youtube dengan kesimpulan bahwa pembelajaran etnomatematika berbasis youtube menggunakan Corel Video Studio X10 berpengaruh positif terhadap kemampuan pemahaman konsep, dan lebih baik dari pada pembelajaran konvensional dengan mengontrol kemampuan awal siswa. Penelitian lain mengenai pengaruh positif pemanfaatan video bahwa kesan pembelajaran berasaskan inquiry dengan integrasi video terhadap pencapaian pelajar dalam pembelajaran matematika lebih sistematik dan efisien (Nur Aqilah Rozali \& Noor Dayana Abd Halim, 2020).

\section{Metode}

Penelitian ini merupakan penelitian tindakan kelas dengan dua siklus yang mengikuti tahapan perencanaan, pelaksanaan, pengamatan dan refleksi (Triyono, 2018). Penelitian ini dilaksanakan di kelas XII DPIB A SMKN 2 Salatiga dengan 34 peserta didik 19 putra dan 15 putri, pada semester gasal 2020-2021. Rancangan penelitian pada siklus 1 diulang pada siklus 2 dengan perbaikan hasil refleksi siklus 1 disusun seperti pada tabel 1 .

Teknik dan alat pengumpulan data penelitian disesuaikan juga dengan jenis variable dapat dilihat pada tabel 2.

Analisis data penelitian menggunakan teknik deskripsi komparatif. Aktivitas belajar dianalisis secara deskripsi kuantitatif berdasarkan lembar kuisioner evaluasi diri yang diisi peserta didik, dan dianalisis secara deskripsi kualitatif berdasarkan lembar pengamatan yang diisi peneliti antara kondisi awal pada siklus 1 dengan kondisi siklus 2. Hasil belajar dianalisis menggunakan deskripsi kuantitatif antara pra-siklus (kondisi awal) dengan siklus 1 dan dengan siklus 2. Setelah deskripsi komparatif dilanjutkan refleksi untuk membandingkan aktivitas dan hasil belajar yang telah dilakukan pada kondisi awal, siklus 1 dan siklus 2 .

\section{Hasil dan Pembahasan}

Hasil penelitian tindakan kelas ini diperoleh dari tindakan pra-siklus (pre-tes) dan menampilkan nilai hasil belajar materi limit fungsi pada tahun ajaran 2019/2020 untuk jurusan yang sama yaitu kelas XII DPIB A. Data penelitian pada tindakan siklus 1 dan tindakan siklus 2 berupa kuisioner evaluasi diri yang diisi peserta didik 
dan observasi dari peneliti dengan pengisian lembar pengamatan untuk aktivitas belajar. Sedangkan hasil belajar berupa nilai tes tertulis online menggunakan aplikasi moodle pada siklus 1 dengan materi limit fungsi $\mathrm{x}$ mendekati nilai tertentu dan pada siklus 2 untuk materi limit fungsi $x$ mendekati nilai tak hingga.

Hasil belajar yang diperoleh pada materi yang sama kelas XII DPIB A tahun 2019/2020 dari 34 peserta didik terdapat 21 peserta didik yang nilainya dibawah KKM dan 13 peserta didik nilainya di atas KKM. Hasil belajar materi limit fungsi tahun sebelumnya menggunakan model pembelajaran konvensional (ceramah dan tanya jawab) dengan rerata kelas 633,82 disajikan pada tabel 3.

Tabel 1. Rancangan Kegiatan Tiap Siklus

\begin{tabular}{|c|c|c|}
\hline $\mathrm{No}$ & Tindakan & Skenario yang dijalankan \\
\hline 1 & Planning & $\begin{array}{l}\text { a. Membuat RPP (skenario dan langkah-langkah pembelajaran); } \\
\text { b. Menyusun butir-butir kuisioner lembar evaluasi diri aktivitas belajar; } \\
\text { c. Menyusun kisi-kisi lembar pengamatan indikator aktivitas belajar peserta didik; } \\
\text { d. Menyusun soal pre-tes, latihan, dan penilaian siklus } 1 \text { dan siklus 2; } \\
\text { e. Validasi soal-soal pre-tes, latihan, dan penilaian oleh teman sejawat; } \\
\text { f. Mengunggah dokumen soal-soal pre-tes (pra kondisi), latihan, dan penilaian siklus1 } \\
\text { dan siklus } 2 \text { ke aplikasi moodle https://youtu.be/W8xEbBsh-Oc } \\
\text { g. Menyiapkan dokumen daftar nilai limit fungsi kelas XII DPIB A tahun kemarin; } \\
\text { h. Menyiapkan media pembelajaran (video youtube) untuk siklus } 1 \text { dan siklus 2; }\end{array}$ \\
\hline 2 & Acting & $\begin{array}{l}\text { a. Melaksanakan kegiatan belajar mengajar (PJJ) secara online menggunakan web } \\
\text { belajar.smkn2salatiga.sch.id, whatsapp, dan aplikasi moodle; } \\
\text { b. Penerapan pendekatan inquiry, peserta didik aktif dalam kegiatan pembelajaran; } \\
\text { c. Peserta didik mempelajari video youtube https://youtu.be/F3QADMadskc; } \\
\text { d. Peserta didik menjawab soal latihan di akhir tayangan video youtube dengan } \\
\text { mengetikkan jawaban akhir di kolom komentar video; } \\
\text { e. Guru menanggapi jawaban peserta didik di kolom komentar video youtube; } \\
\text { f. Diskusi dan tanya jawab interaktif di kolom chatting portal media belajar sekolah } \\
\text { maupun grup wa untuk mengarahkan keaktivan belajar peserta didik; } \\
\text { g. Guru mengamati dan mencatat keaktivan belajar peserta didik melalui berbagai kanal } \\
\text { media pembelajaran yang tersedia; } \\
\text { h. Peserta didik berlatih (drill and practice) melalui aplikasi moodle di pertemuan ke-2; } \\
\text { i. Guru melayani konsultasi pertanyaan peserta didik setelah pertemuan ke-2; } \\
\text { j. Pertemuan ke-3 peserta didik melaksanakan penilaian melalui aplikasi moodle; } \\
\text { k. Setelah penilaian siklus 1, peserta didik diminta mengisi lembar evaluasi diri. }\end{array}$ \\
\hline 3 & Observing & $\begin{array}{l}\text { a. Mengamati aktivitas belajar siswa dalam kegiatan mengajar dan latihan melalui } \\
\text { catatan dalam proses pembelajaran; } \\
\text { b. Pengamatan aktivitas belajar peserta didik siklus 1; } \\
\text { c. Aktivitas belajar peserta didik terekam dari isian lembar kuisioner evaluasi diri dan } \\
\text { isian lembar pengamatan aktivitas belajar peserta didik yang diisi oleh guru; } \\
\text { d. Hasil belajar peserta didik siklus } 1 \text { diperoleh dari penilaian akhir yang mencerminkan } \\
\text { penguasaan konsep dan kemampuan peserta didik dibandingkan nilai hasil pre-tes } \\
\text { dan daftar nilai kelas tahun kemarin; } \\
\text { e. Pengamatan teknik dan alat observasi hasil siklus I direfleksikan untuk perbaikan } \\
\text { siklus } 2 \text {. }\end{array}$ \\
\hline 4 & Reflecting & $\begin{array}{l}\text { a. Evaluasi siklus } 1 \text { untuk diperbaiki di siklus } 2 \text {; } \\
\text { b. Refleksi untuk mengamati proses, yaitu apa yang telah dan belum terjadi, apa yang } \\
\text { dihasilkan, mengapa bisa terjadi dan tindakan apa yang perlu dilakukan; } \\
\text { c. Kendala-kendala PJJ diatasi agar menjangkau aktivitas belajar semua peserta didik; } \\
\text { d. Mendata kemungkinan kelemahan sistem pembelajaran jika ada, misalnya kesulitan } \\
\text { peserta didik dalam mengakses pembelajaran online; } \\
\text { e. Evaluasi dilakukan terhadap konten video pembelajaran dan unggahan penilaian; } \\
\text { f. Keterbatasan tiga pertemuan pembelajaran di siklus } 1 \text { diperbaiki pada siklus } 2 \text {; } \\
\text { g. Antisipasi tingkat kesulitan materi siklus } 1 \text { dan siklus } 2 \text {. }\end{array}$ \\
\hline
\end{tabular}


Tabel 2. Teknik dan Pengumpul Data

\begin{tabular}{llll}
\hline No & Variabel & Teknik Pengumpulan Data & Alat Pengumpul Data \\
\hline 1 & Aktivitas belajar & Pengisian kuisioner evaluasi diri, & Lembar kuisioner evaluasi diri \\
& & Pengamatan aktivitas peserta didik & Lembar pengamatan (non-tes) \\
2 & Hasil belajar & Hasil belajar kelas tahun kemarin & Tes tertulis \\
& & Pre-tes dan penilaian akhir sub-bab & Tes tertulis \\
\hline
\end{tabular}

Tabel 3. Hasil Belajar Tahun 2019/2020

\begin{tabular}{lllll}
\hline No & Nilai & Jumlah Peserta Didik & Persentase (\%) & Keterangan \\
\hline 1 & $<75$ & 21 & 61.76 & Tidak tuntas \\
2 & $>75$ & 13 & 38.24 & Tuntas \\
\hline & Jumlah & 34 & 100 & Ketuntasan $38,24 \%$ \\
\hline
\end{tabular}

Sedangkan hasil belajar yang diperoleh di awal penelitian dari 34 peserta didik pada materi limit fungsi menggunakan aplikasi moodle terdapat 28 peserta didik yang nilainya di bawah KKM, 2 peserta didik nilainya di atas KKM, dan 4 peserta didik tidak mengikuti pre-tes. Hasil evaluasi belajar pre-tes dengan rerata kelas hanya 416,67 tersebut disajikan pada tabel 4 .

Tabel 4. Hasil Pre-Tes

\begin{tabular}{lllll}
\hline No & Nilai & Jumlah Peserta Didik & Persentase (\%) & Keterangan \\
\hline 1 & Tidak Ikut & 4 & 11.76 & Tidak Ikut \\
2 & $<75$ & 28 & 82.35 & Tidak Tuntas \\
3 & $\geq 75$ & 2 & 5.88 & Tuntas \\
\hline & Jumlah & 34 & 100 & Ketuntasan $5,88 \%$ \\
\hline
\end{tabular}

\section{Aktivitas dan Hasil Belajar Siklus 1}

Berdasarkan hasil tes tertulis online siklus 1 diketahui bahwa hasil belajar peserta didik mengalami peningkatan dibandingkan dengan hasil belajar pada kondisi awal (pre tes) maupun hasil belajar materi limit fungsi tahun 2019/2020. Secara rerata kelas sebesar 850 sudah melampaui KKM (750), tetapi persentase ketuntasan kelas sebesar $67,65 \%$ belum melampaui target ketuntasan kelas minimal ( $\geq 85 \%$ ). Hasil penilaian dapat dilihat pada tabel 5 .

Tabel 5. Hasil Penilaian Siklus 1

\begin{tabular}{cllll}
\hline No & Nilai & Jumlah Peserta Didik & Persentase & Keterangan \\
\hline 1 & Tidak Ikut & 4 & 11.76 & Tidak Ikut \\
2 & $<75$ & 7 & 20.59 & Tidak Tuntas \\
3 & $\geq 75$ & 23 & 67.65 & Tuntas \\
\hline & Jumlah & 34 Peserta Didik & $100 \%$ & Ketuntasan $67,65 \%$ \\
\hline
\end{tabular}

Sumber penilaian aktivitas belajar peserta didik diperoleh dari pengisian kuisioner evaluasi diri selama pembelajaran siklus 1 dengan hasil dapat dilihat pada tabel 6 .

Tabel 6. Aktivitas Peserta Didik Hasil Evaluasi Diri Siklus 1

\begin{tabular}{cllll}
\hline No & Skor & Jumlah Peserta Didik & Persentase (\%) & Keterangan \\
\hline 1 & Tidak menjawab & 3 & 8.82 & Tidak Aktif \\
2 & $10-17$ & 0 & 0.00 & $20.59 \%$ \\
3 & $18-25$ & 4 & 11.76 & Aktif \\
4 & $26-33$ & 24 & 70.59 & $79.41 \%$ \\
5 & $34-40$ & 3 & 8.82 & $100 \%$ \\
\hline
\end{tabular}

Pembelajaran model konvensional (ceramah) menyampaikan konsep limit fungsi dengan peserta didik menerima secara pasif penyampaian guru dan mengikuti penilaian di akhir pembelajaran terbukti belum tentu menghasilkan aktivitas dan hasil belajar yang optimal. Aktivitas belajar peserta didik pada pembelajaran 
konvensional memang terlihat peserta didik mengikuti proses kegiatan belajar mengajar dengan mencatat materi, berlatih soal, dan mengerjakan penilaian di akhir pertemuan. Tetapi antuasiasme, inisiatif, kemandirian, semangat dan motivasi belajar tidak terukur secara valid dan eksplisit.

Indikator aktivitas belajar pada model pembelajaran jarak jauh (online) saat ini (aktif belajar online, bertanya/chatting, mempelajari materi, menyimak video, berlatih soal, mencari sumber belajar lain, berkomunikasi, review materi, mempersiapkan ujian, dan mengikuti penilaian) tidak secara utuh bisa digunakan dan diterapkan pada pembelajaran tatap muka. Diperlukan penyesuaian ketentuan indikator-indikator yang berbeda dalam perspektif pertemuan tatap muka untuk menilai dan mengukur aktivitas belajar secara offline. Penilaian guru dalam membandingkan aktivitas belajar tatap muka/offline dengan aktivitas belajar daring/online diukur dari pengamatan terhadap semangat, motivasi, antusiasme, dan berbagai perilaku lainnya dari peserta didik dalam keikutsertaan proses pembelajaran.

\section{Perbandingan Aktivitas dan Hasil Belajar Model Konvensional (Ceramah) dengan Pendekatan Inquiry Model Drill and Practice Berbasis Aplikasi Moodle Berbantuan Video Youtube}

Rendahnya aktivitas belajar dalam pendekatan model pembelajaran konvensional tahun 2019/2020 terbukti berbanding lurus dari hasil belajar yang tidak maksimal. Terlihat rerata hasil belajar tatap muka tahun 2019/2020 pada materi yang sama (limit fungsi), dari kelas jurusan yang sama (XII DPIB A) hanya 633,82 (di bawah KKM 750) dengan ketuntasan kelas 38,24 \% (jauh dari batas minimal 85\%). Sedangkan hasil belajar dengan pendekatan inquiry model drill and practice berbasis aplikasi moodle berbantuan video youtube pada penelitian ini rerata kelas mencapai 850,00 (di atas KKM 750) dengan ketuntasan kelas 67,65\% pada siklus 1. Hasil siklus 1 meningkat pada siklus 2 dengan rerata kelas 912,90 (jauh di atas KKM 750) dan ketuntasan kelas 91,18\% (jauh di atas batas minimal 85\%). Pada tabel 7, perbandingan hasil belajar model konvensional dengan pendekatan inquiry.

Tabel 7. Perbandingan Hasil Belajar Model Ceramah dengan Pendekatan Inquiry

\begin{tabular}{llll}
\hline Aspek Hasil Belajar & $\begin{array}{l}\text { Model Ceramah } \\
\text { (Konvensional) }\end{array}$ & $\begin{array}{l}\text { Pendekatan Inquiry } \\
\text { Siklus 1 }\end{array}$ & $\begin{array}{l}\text { Pendekatan Inquiry } \\
\text { Siklus 2 }\end{array}$ \\
\hline Nilai Rerata Kelas & 633,82 & 850,00 & 912,90 \\
Ketuntasan Kelas & $38,24 \%$ & $67,65 \%$ & $91,18 \%$ \\
\hline
\end{tabular}

Pada hasil belajar pendekatan inquiry siklus 1 ketuntasan kelas masih di bawah target (minimal 85\%) dikarenakan adanya 4 peserta didik (11,76\%) yang tidak mengikuti penilaian akhir dan 7 peserta didik (20,59\%) yang tidak tuntas sehingga gabungan dua kategori ini menjadi 32,35\%. Salah satu kendala pembelajaran online memang sulitnya memastikan akses dan peran serta peserta didik terhadap proses pembelajaran dan penilaian, sangat berbeda dengan pembelajaran tatap muka yang lebih mudah memastikan partisipasi dan keikutsertaan peserta didik dalam proses pembelajaran dan penilaian.

Akan tetapi pada siklus 2, situasi dan kondisi yang terjadi pada siklus 1 relatif dapat diperbaiki secara hasil akhir dan partisipasi saat proses pembelajaran dan penilaian meningkat. Hal ini terlihat dan terbukti dengan hasil belajar yang meningkat signifikan pada rerata kelas menjadi 912,90 (meningkat 62,90 poin dari siklus 1) dengan ketuntasan kelas juga meningkat signifikan sebesar 23,53\% (dari siklus 1 sebesar 67,65\% menjadi 91,18\%). Pada siklus 2 berkurang satu peserta didik yang tidak mengikuti penilaian akhir (dari 4 menjadi 3 peserta didik), dan keseluruhan 31 peserta didik yang mengikuti penilaian akhir semuanya tuntas.

Perbandingan aktivitas belajar model ceramah (konvensional) dengan pendekatan inquiry tidak sekadar membandingkan pembelajaran daring/online dengan pembelajaran tatap muka/offline. Pendekatan inquiry model drill and practice berbasis aplikasi moodle berbantuan video youtube pun juga akan sangat efektif diterapkan saat pembelajaran tatap muka karena peserta didik bisa dikondisikan membawa smartphone ke sekolah, bahkan didukung jaringan internet/wifi sekolah yang stabil. Karena itu 10 indikator aktivitas belajar daring/online di atas (aktif belajar online, bertanya/chatting, mempelajari materi, menyimak video, berlatih soal, mencari sumber belajar lain, berkomunikasi, review materi, mempersiapkan ujian, dan mengikuti penilaian) bisa diadaptasi seperlunya bila pembelajaran dilakukan secara tatap muka/offline. 


\section{Perbandingan Aktivitas dan Hasil Belajar Pra-Siklus dengan Siklus 1}

Aktivitas belajar sebelum pre-tes bisa diamati dari kegiatan belajar peserta didik saat mempelajari video youtube di materi statistika sebelum limit fungsi. Aktivitas belajar peserta didik relatif antusias dan semangat dalam belajar. Tetapi penilaian akhir bab tidak menggunakan aplikasi moodle dan nilai diambilkan dari tugas mengerjakan soal di tayangan youtube dengan mengetikkan jawaban akhirnya di kolom komentar video. Bentuk lain pengumpulan tugas dengan memfoto hasil pengerjaan dan dikirimkan ke folder media belajar.smkn2salatiga.sch.id.

Sedangkan pada materi limit fungsi aljabar pre-tes menggunakan model soal pilihan ganda yang diunggah di aplikasi moodle dengan dibatasi waktu pengerjaannya, sehingga hasil penilaian relatif lebih valid dan terukur, apalagi sistem moodle yang mengacak soal dan opsi jawaban. Model ini dipakai untuk penilaian siklus 1 dan siklus 2, termasuk latihan soal terstruktur sebelum peserta didik mengikuti penilaian akhir tersebut. Soal pre-tes menguji gabungan materi siklus 1 dan siklus 2 (limit fungsi aljabar x mendekati nilai tertentu dan $\mathrm{x}$ mendekati nilai tak hingga).

Salah satu faktor penilaian online yang terukur inilah menyebabkan nilai pre-tes materi limit fungsi aljabar peserta didik menjadi rendah karena peserta didik memang belum menerima materi pembelajaran. Nilai rerata kelas peserta didik pada saat kondisi awal (pre-tes) menunjukkan kemampuan dan penguasaan konsep mereka yang memang belum ada. Nilai rerata kelas hanya 416,67 (jauh di bawah KKM 750) dengan ketuntasan kelas sebesar 5,88\%, hanya dua orang yang tuntas dari 34 peserta didik (jauh di bawah batas minimal ketuntasan kelas $85 \%)$.

Setelah pembelajaran dimulai dengan pendekatan inquiry, peserta didik mulai memahami konsep limit fungsi dari orientasi dan stimulus materi yang disampaikan melalui tayangan video youtube. Peserta didik melakukan penyelidikan, menjawab keraguan terhadap konsep-konsep limit melalui diskusi dan tanya jawab interaktif di grup whatshap maupun konsultasi pribadi. Kemudian pemahaman dan penguasaan konsep dasar limit fungsi diperkuat dengan latihan-latihan mandiri (drill and practice), baik soal dari bagian akhir tayangan video youtube maupun yang terstruktur pada aplikasi moodle.

Perencanaan dan persiapan panjang sebelum pembelajaran menggunakan pendekatan inquiry model drill and practice berbasis aplikasi moodle berbantuan video youtube memang jauh lebih menguras tenaga dan waktu dibandingkan penggunaan model konvensional (ceramah). Guru harus membuat konten video pembelajaran, menyusun soal-soal pre-tes, latihan, dan penilaian kemudian diunggah di aplikasi moodle. Dan terakhir guru sebagai fasilitator dan pendamping bagi peserta didik harus mengawal proses pembelajaran menggunakan model pendekatan inquiry secara online melalui berbagai media belajar interaktif dengan multi peran menjawab, menerima konsultasi, dan mengarahkan aktivitas belajar.

Dengan tahapan proses belajar siklus 1 yang berjalan sesuai perencanaan, hasil belajar peserta didik terlihat menunjukkan hasil yang relatif baik walaupun belum benar-benar memuaskan. Pada siklus 1 rerata kelas sudah baik (di atas KKM 750) yaitu 850,00 tetapi ketuntasan kelas masih tertahan di angka 67,65\%. Dibandingkan pada tahap kondisi awal pra-siklus pencapaian nilai rerata kelas ini sudah meningkat 423,33 dan ketuntasan kelas juga meningkat signifikan sebesar $61,77 \%$. Perbandingan kenaikan nilai rerata kelas dan ketuntasan kelas disajikan pada tabel berikut:

Tabel 8. Perbandingan Hasil Belajar Pra-Siklus dengan Siklus 1

\begin{tabular}{llll}
\hline Aspek Hasil Belajar & Pra-Kondisi Awal (Pre-Tes) & Pendekatan Inquiry Siklus 1 & Kenaikan \\
\hline Nilai Rerata Kelas & 426,67 & 850,00 & 423,33 \\
Ketuntasan Kelas & $5,88 \%$ & $67,65 \%$ & $61,77 \%$ \\
\hline
\end{tabular}

Pada kondisi awal (pre-tes) terlihat sudah ada dua peserta didik yang tuntas disebabkan adanya indikasi aktivitas belajar mereka. Bisa jadi dua peserta didik tersebut sudah mempelajari materi yang diunggah melalui tayangan video youtube secara mandiri. Sedangkan sebagian besar peserta didik lain pasrah menghadapi pre-tes tanpa persiapan walaupun skenario pembelajaran ini sudah disampaikan jauh beberapa hari sebelumnya. Mayoritas peserta didik mengerjakan pre-tes sebatas kemampuan dan pemahaman konsep yang dimiliki. Bahkan pada saat pre-tes ada 4 peserta didik yang tidak mengikutinya. 
Aktivitas dan Hasil Belajar Siklus 2

Sumber penilaian aktivitas belajar peserta didik diperoleh dari pengisian kuisioner evaluasi diri selama pembelajaran siklus 2 dengan hasil dapat dilihat pada tabel 9 .

Dibandingkan siklus 1 terlihat kenaikan persentase aktivitas belajar yang signifikan sebesar 8,83\% (meningkat dari 79,41 \% menjadi 88,24\%) untuk hasil pengisian kuisioner evaluasi diri yang meliputi 10 aspek (aktif belajar online, bertanya, mempelajari materi, menyimak video, berlatih soal, mencari sumber belajar lain, berkomunikasi, review materi, mempersiapkan ujian, dan mengikuti penilaian).

Tabel 9. Aktivitas Belajar Berdasarkan Evaluasi Diri Siklus 2

\begin{tabular}{lllll}
\hline No & Skor & Jumlah Peserta Didik & Persentase (\%) & Keterangan \\
\hline 1 & Tidak menjawab & 4 & 11.76 & Tidak Aktif \\
2 & $10-17$ & 0 & 0.00 & $11.76 \%$ \\
3 & $18-25$ & 0 & 0.00 & Aktif \\
4 & $26-33$ & 28 & 82.35 & $88.24 \%$ \\
5 & $34-40$ & 2 & 5.88 & $100 \%$ \\
\hline & Jumlah & 34 & 100 & \\
\hline
\end{tabular}

Sumber lain penilaian aktivitas belajar peserta didik berasal dari pengamatan guru terhadap partisipasi aktif mereka selama kurun waktu pembelajaran siklus 2. Pengamatan aktivitas belajar peserta didik ini dilihat dari partisipasi aktif melalui berbagai media pembelajaran jarak jauh yaitu presensi kehadiran di media belajar.smkn2salatiga.sch.id, komentar jawaban peserta didik pada video youtube, dialog/chatting jawab pribadi maupun interaksi dalam grup, serta latihan dan penilaian peserta didik pada aplikasi moodle.

Berikut hasil pengamatan peneliti terhadap aktivitas belajar peserta didik yang meningkat cukup signifikan sebesar 11,77 \% dari capaian 79,41 \% pada siklus 1 menjadi 91,18\% pada siklus 2 :

Tabel 10. Aktivitas Belajar Peserta Didik Siklus 2 Berdasarkan Pengamatan Guru

\begin{tabular}{lllll}
\hline No & Kategori & Jumlah Peserta Didik & Persentase (\%) & Keterangan \\
\hline 1 & Kurang Aktif & 2 & 5.88 & Tidak Aktif \\
2 & Agak Aktif & 1 & 2.94 & $8,82 \%$ \\
3 & Aktif & 16 & 47.06 & Aktif \\
4 & Sangat Aktif & 15 & 44.12 & $91,18 \%$ \\
\hline & Jumlah & 34 & 100 & $100 \%$ \\
\hline
\end{tabular}

Berdasarkan hasil tes tertulis online siklus 2 diketahui bahwa hasil belajar peserta didik mengalami peningkatan signifikan dibandingkan dengan hasil belajar pada siklus 1 . Rerata kelas siklus 2 meningkat sebanyak 62,90 menjadi 912,90 dari siklus 1 sebesar 850,00. Sedangkan persentase ketuntasan kelas sebesar 91,18 \% sudah jauh melampaui target dari indikator ketuntasan kelas minimal ( $\geq 85 \%)$, dengan kenaikan signifikan sebesar 23,53 \% dibandingkan hasil penilaian siklus 1 (67,65 \%).

Tabel 11. Hasil Belajar Siklus 2

\begin{tabular}{lllll}
\hline No & Nilai & Jumlah Peserta Didik & Persentase $(\%)$ & Keterangan \\
\hline 1 & Tidak Ikut & 3 & 8,82 & Tidak Ikut \\
2 & $<75$ & 0 & 0 & Tidak Tuntas \\
3 & $\geq 75$ & 31 & 91,18 & Tuntas \\
\hline & Jumlah & 34 & 100 & Ketuntasan $\mathbf{9 1 , 1 8 \%}$ \\
\hline
\end{tabular}

\section{Perbandingan Aktivitas Belajar Siklus 1 dengan Siklus 2}

Aktivitas belajar pada siklus 1 sudah memenuhi indikator kinerja yang ditetapkan di awal penelitian, baik melalui pengisian kuisioner evaluasi diri peserta didik maupun lembar observasi aktivitas belajar peserta didik yang diamati oleh guru. Indikator pertama bahwa minimal 75\% peserta didik mencapai kategori aktif (skor 2633) saat pembelajaran online baik proses kegiatan belajar mengajar, belajar mandiri, maupun pengerjaan latihan dan ujian melalui pengisian lembar kuisioner evaluasi diri. Hasil penelitian aktivitas belajar siklus 1 menunjukkan 79,41\% peserta didik aktif, sedangkan sisanya sebesar 20,59\% tidak aktif. 
Kategori peserta didik aktif sebesar 79,41\% merupakan gabungan dari mereka yang menjawab sering dan selalu pada 10 indikator kegiatan yang menunjukkan aktivitas belajar mereka selama berlangsungnya siklus 1 . Sedangkan peserta didik tidak aktif sebesar 20,59\% merupakan gabungan dari mereka yang menjawab tidak pernah dan kadang-kadang pada 10 indikator aktivitas belajar selama siklus 1 (ditambah 4 peserta didik yang tidak mengirimkan lembar kuisioner evaluasi diri). Sebenarnya kesediaan peserta didik mengisi lembar kuisioner dan mengirimkannya melalui email sudah menunjukkan kesungguhan dan keaktivan mereka dalam belajar.

Sumber penilaian aktivitas belajar peserta didik selain kuisioner evaluasi diri diperoleh melalui instrumen pengamatan guru. Indikator kinerja ditentukan di awal penelitian bahwa minimal 75\% peserta didik mencapai predikat aktif jika peserta didik sering ikut pembelajaran online, sering bertanya di forum dialog/chatting, dan sering mengerjakan soal latihan/ujian. Hasil akhir pengamatan ini ternyata menunjukkan angka yang sama dengan sumber data pertama kuisioner evaluasi diri, yaitu 79,41\% peserta didik aktif, sedangkan sisanya sebesar 20,59\% tidak aktif.

Kriteria peserta didik aktif sebesar 79,41\% diperoleh dari mereka yang aktif (22 anak) dan sangat aktif (5 anak) dalam proses pembelajaran daring sebanyak 27 peserta didik. Sedangkan kriteria tidak aktif sebesar 20,59\% merupakan gabungan peserta didik yang kurang aktif ( 3 anak) dan agak aktif (4 anak) selama proses pembelajaran online sebanyak 7 peserta didik. Di antara beberapa faktor penyebab peserta didik tidak aktif karena kesulitan akses internet di lingkungan tempat tinggal mereka yang jauh dari kota dan keterbatasan kuota data yang memang bagi sebagian anak mengalami kesulitan pembiayaan. Pembelajaran jarak jauh secara online sangat tergantung pada kuota data dan kuat tidaknya jaringan internet. Banyak peserta didik yang mengalami kendala sulit mengakses jaringan internet.

Kondisi aktivitas belajar peserta didik pada siklus 2 mengalami peningkatan cukup signifikan terlihat dari sumber data kuisioner evaluasi diri dan instrumen pengamatan yang diisi guru. Pada lembar kuisioner evaluasi diri peserta didik yang aktif mencapai 88,24\% terdiri dari 28 anak yang aktif dan 2 anak sangat aktif, sedangkan peserta didik yang tidak aktif hanya 4 anak itupun karena mereka tidak mengisi atau tidak mengirimkan lembar kuisioner evaluasi diri (faktor kesulitan akses internet). Jika pembelajaran berlangsung offline secara tatap muka dengan peserta didik hadir di kelas, bisa dipastikan mereka juga akan mengisi kuisioner tersebut.

Untuk instrumen pengamatan aktivitas peserta didik yang diisi guru pada siklus 2, terlihat hasil bahwa 91,18\% peserta didik aktif (16 anak aktif dan 15 anak sangat aktif), sedangkan 8,82\% peserta didik tidak aktif ( 2 anak kurang aktif dan 1 anak agak aktif). Kenaikan aktivitas belajar peserta didik yang meningkat sebesar 8,83\% (dari instrumen lembar kuisioner evaluasi diri) dan sebesar 11,77\% (dari instrumen lembar pengamatan guru) disajikan pada tabel 12 .

Tabel 12. Perbandingan Aktivitas Belajar Siklus 1 dengan Siklus 2

\begin{tabular}{llll}
\hline Instrumen Aktivitas Belajar & Siklus 1 (19-28 Agustus 2020) & Siklus 2 (9-18 September 2020) & Kenaikan \\
\hline Evaluasi Diri & $79,41 \%$ & $88,24 \%$ & $8,83 \%$ \\
Pengamatan Guru & $79,41 \%$ & $91,18 \%$ & $11,77 \%$ \\
\hline
\end{tabular}

Pada siklus 1 semua lembar kuisioner evaluasi diri setelah diisi dikirimkan melalui email. Mekanisme ini memerlukan proses yang lama dan beberapa peserta didik harus diingatkan kalau belum mengirimkan lembar kuisioner. Beberapa peserta didik bahkan ada yang mengirimkan lembar kuisioner kosong karena belum disimpan setelah mengisi. Di antara peserta didik ada yang meggunakan perangkat laptop dan ada yang cukup menggunakan smartphone. Beberapa smartphone yang digunakan ada yang didukung fitur-fitur lengkap, tetapi juga ada yang terbatas. Fakta-fakta ini menyebabkan beragam kendala dan tantangan pengkondisian proses pembelajaran.

Salah satu penyikapan kendala yang terjadi pada siklus 1 diperbaiki pada siklus 2 dengan memperpanjang waktu pelaksanaan. Pada siklus 2 pengisian lembar kuisioner evaluasi diri dialokasikan dengan waktu khusus di akhir pertemuan pada hari Jumat 18 September 2020. Penyikapan lain dengan mekanisme pengisian lembar kuisioner evaluasi diri cukup di grup whatshapp walaupun peserta didik boleh mengirimkan melalui gmail. Dan mekanisme ini cukup berhasil dengan indikator dalam dua jam pelajaran telah terkumpul kuisioner tersebut, berbeda dengan pelaksanaan pada siklus 1 yang memerlukan waktu beberapa hari. 
Secara umum aktivitas belajar yang menonjol pada siklus 1 dan siklus 2 ini adalah menyimak dan mempelajari orientasi materi pada video youtube dengan indikator rating angka views-nya baik video siklus 1 maupun video siklus 2 semakin meningkat pada saat proses siklus pembelajaran berlangsung. Aktivitas belajar kedua setelah menyimak dan mempelajari video youtube adalah berlatih (drill and practice) dengan menjawab latihan soal di bagian akhir video dan mengetikkan jawaban akhir pada kolom komentar. Hal ini dapat dilihat dari jumlah komentar di masing-masing video. Yang menjadi kendala pada proses ini adalah banyaknya komentar peserta didik yang hilang karena dianggap spam oleh server youtube.

Aktivitas belajar terstruktur lainnya diamati dari diskusi, interaksi, dan tanya jawab di media belajar.smkn2salatiga.sch.id dan grup whatsapp kelas saat berlangsung proses pembelajaran. Pembelajaran daring/online yang dibatasi waktunya satu jam pelajaran@30 menit (jam pelajaran normal tatap muka@ 45 menit) menjadi salah satu keterbatasan yang harus diterima. Selain itu kendala jaringan internet harus disiasati agar peserta didik selalu dapat mengakses dan mengikuti pembelajaran maupun penilaian online.

Aktivitas belajar terstruktur berikutnya adalah latihan soal (drill and practice) melalui aplikasi moodle baik pada siklus 1 maupun siklus 2. Jika latihan soal pada tayangan video youtube kurang terkontrol karena banyaknya kendala teknis, maka latihan soal menggunakan aplikasi moodle lebih terkontrol dengan baik karena semua jawaban peserta didik terekam oleh sistem. Karena itu penilaian hasil belajar setiap siklus yang menggunakan aplikasi moodle ini bersifat valid dan dapat dipertanggungjawabkan. Peserta didik mengerjakan penilaian akhir siklus dengan sistem yang sama yang pernah mereka kerjakan di sesi latihan sebelumnya.

Durasi dan kapan peserta didik mengerjakan penilaian terdata pada sistem aplikasi moodle. Jawaban soal nomor awal sampai terakhir juga dapat dianalisis dari rekam jejak hasil pengerjaan. Dan perbedaan sesi latihan dengan penilaian hanya terletak pada ragam soal yang dibuat. Proses pengerjaan latihan dan penilaian ini menjadi salah satu indikator pengamatan aktivitas belajar peserta didik, baik pada butir lembar kuisioner evaluasi diri maupun instrumen pengamatan guru. Parameter aktivitas belajar peserta didik yang terakhir adalah refleksi pembelajaran di akhir siklus dengan mengisi lembar kuisioner dan penyampaian laporan hasil belajar tiap siklus kepada peserta didik agar menjadi bahan evaluasi menghadapi materi pembelajaran berikutnya yaitu turunan fungsi.

\section{Perbandingan Hasil Belajar Siklus 1 dengan Siklus 2}

Ada dua indikator kinerja peningkatan variabel hasil belajar. Indikator pertama minimal nilai rerata hasil penilaian kelas adalah 750, dengan kata lain nilai rerata kelas di atas nilai KKM yang ditentukan sebesar 750 . Hasil belajar peserta didik pada siklus 1 berdasarkan rerata nilai kelas sudah melampai batas minimal KKM (750) yaitu 850,00 . Hasil nilai ini meningkat signifikan sebesar 62,90 poin menjadi 912,90 pada siklus 2 . Indikator kedua minimal ketuntasan kelas adalah $85 \%$, dengan kata lain lebih dari $85 \%$ peserta didik tuntas mencapai nilai KKM. Hasil belajar peserta didik berdasarkan kriteria ini belum memenuhi indikator kinerja pada siklus 1 karena hanya mencapai $67,65 \%$ tetapi pada siklus 2 dapat ditingkatkan menjadi 91,18\% sehingga terhitung meningkat signifikan sebesar 23,53\%. Peningkatan hasil belajar dari siklus 1 ke siklus 2 disajikan pada tabel 13 .

Tabel 13. Perbandingan Hasil Belajar Siklus 1 dengan Siklus 2

\begin{tabular}{llll}
\hline Aspek Hasil Belajar & Siklus 1 (19-28 Agustus 2020) & Siklus 2 (9-18 September 2020) & Kenaikan \\
\hline Nilai Rerata Kelas & 850,00 & 912,90 & 62,90 \\
Ketuntasan Kelas & $67,65 \%$ & $91,18 \%$ & $23,53 \%$ \\
\hline
\end{tabular}

Sudah terpenuhinya indikator pertama nilai rerata kelas yang mencapai target di atas KKM (750) baik pada siklus 1 maupun siklus 2 menunjukkan korelasi positif antara aktivitas belajar dengan hasil belajar. Aktivitas belajar yang meningkat berdampak pada prestasi hasil belajar yang juga bagus, baik menggunakan perbandingan dengan kondisi pembelajaran tatap muka metode konvensional tahun sebelumnya maupun perbandingan antara siklus 1 dengan siklus 2. Nilai rerata kelas yang melampaui KKM diperoleh dari capaian nilai individu peserta didik yang mengerjakan penilaian akhir setiap siklus dengan sungguh-sungguh setelah melalui proses aktivitas belajar yang optimal.

Belum terpenuhinya target indikator kinerja dari aspek ketuntasan kelas pada siklus 1 salah satu faktor penyebabnya adalah adanya 4 peserta didik $(11,76 \%)$ yang tidak mengikuti penilaian siklus 1 sehingga menambah persentase peserta didik yang ikut penilaian tapi tidak tuntas dari 20,59\% (7 anak) menjadi 32,35\% 
(11 anak). Sebenarnya ada kemungkinan 4 peserta didik yang tidak mengikuti penilaian akan memperoleh nilai di atas KKM sehingga menambah persentase ketuntasan kelas jika mereka mengikuti sesi penilaian akhir. Hal ini terbukti pada siklus 2 semua peserta didik yang mengikuti sesi penilaian akhir bisa semuanya tuntas nilai di atas KKM sebanyak 91,18\% (31 anak). Persentase ketidaktuntasan sebesar 8,82\% (3 anak) dikarenakan peserta didik yang tidak ikut sesi penilaian akhir.

Walaupun kriteria ketuntasan kelas tidak tercapai pada siklus 1, peningkatan hasil belajar baik dari kondisi awal (pra-siklus) menuju siklus 1 dan berlanjut siklus 2 maupun dari model konvensional tahun 2019/2020 dibandingkan pendekatan inquiry pada penelitian ini menunjukkan pembuktian hipotesis penelitian adanya peningkatan hasil belajar. Pendekatan inquiry pada penelitian ini dimaksudkan dengan upaya mandiri peserta didik untuk memahami konsep limit fungsi melalui stimulus tayangan video youtube yang disimak di awal pembelajaran. Setelah peserta didik memahami konsep limit fungsi aljabar, penguasaan pemahamannya dilatih dengan mengerjakan soal latihan (drill and practice) di bagian akhir tayangan video youtube.

Secara lebih terstruktur, latihan soal (drill and practice) pada materi limit fungsi aljabar ini diberikan melalui aplikasi moodle dengan durasi waktu pengerjaan secara terjadwal, berbeda dengan model latihan mandiri pada video youtube. Semua tahapan strategi pengajaran ini dilakukan peserta didik secara mandiri dalam pembelajaran jarak jauh (online) menggunakan pendekatan inquiry. Pertemuan pertama orientasi materi dengan tayangan video youtube dilanjutkan diskusi dan tanya jawab. Pertemuan kedua berlatih soal dengan aplikasi moodle secara terjadwal dan terstruktur. Pertemuan ketiga peserta didik mengerjakan penilaian akhir menggunakan aplikasi moodle, diakhiri dengan refleksi mengisi lembar kuisioner evaluasi diri. Khusus siklus 2 refleksi memanfaatkan satu pertemuan tersendiri agar lebih terkontrol.

\section{Simpulan}

Aktivitas belajar pada siklus 1 berdasarkan evaluasi diri peserta didik menunjukkan 7 anak (20,59\%) tidak aktif sedangkan 27 anak (79,41\%) aktif dalam proses pembelajaran. Angka ini meningkat pada siklus 2 dengan capaian 4 anak (11,76\%) yang tidak aktif dan 30 anak (88,24\%) aktif berpartisipasi dalam proses pembelajaran. Kenaikan persentase aktivitas peserta didik dalam proses pembelajaran dari siklus 1 ke siklus 2 sebesar $8,83 \%$. Aktivitas belajar pada siklus 1 berdasarkan instrumen pengamatan guru menunjukkan 7 anak $(20,59 \%)$ tidak aktif sedangkan 27 anak $(79,41 \%)$ aktif dalam proses pembelajaran. Pencapaian ini meningkat pada siklus 2 yang menunjukkan 3 anak (8,82\%) tidak aktif dan sebanyak 31 anak $(91,18 \%)$ terkategorikan aktif mengikuti proses pembelajaran. Kenaikan persentase aktivitas peserta didik dalam proses pembelajaran dari siklus 1 ke siklus 2 sebesar $11,77 \%$.

Hasil belajar peserta didik pada materi limit fungsi aljabar siklus 1 menunjukkan rerata kelas sebesar 850,00 (di atas batas minimal KKM 750) dan meningkat menjadi 912,90 pada siklus 2 sehingga kenaikannya sebesar 62,90. Sedangkan ketuntasan kelas pada siklus 1 menunjukkan adanya 11 anak (32,35\%) tidak tuntas dan selebihnya 23 anak $(67,65 \%)$ tuntas mengerjakan penilaian akhir. Hasil belajar siklus 2 meningkat sebesar 23,53\% menjadi 3 anak (8,82\%) yang tidak tuntas, selebihnya 31 anak (91,18\%) tuntas mengerjakan penilaian akhir.

Jadi dapat disimpulkan bahwa penerapan pendekatan inquiry model drill and practice berbasis aplikasi moodle berbantuan video youtube terbukti berhasil meningkatkan aktivitas dan hasil belajar materi limit fungsi pada peserta didik kelas XII DPIB A di SMKN 2 Salatiga Semester Gasal 2020/2021.

\section{Ucapan Terima Kasih}

Penulis menyampaikan apresiasi dan terima kasih sebanyak-banyaknya kepada peserta didik kelas XII DPIB A yang telah mengikuti proses kegiatan belajar-mengajar secara online ini dengan semangat dan antusias sehingga proses penelitian tindakan kelas ini dapat berjalan dengan baik tanpa suatu halangan apapun.

\section{Daftar Pustaka}

Agus, R. N. (2018). Aplikasi Metode Pembelajaran Inquiry Berbantuan Maple dalam Meningkatkan Hasil dan Motivasi Belajar pada Materi Limit Fungsi. https://doi.org/10.31227/osf.io/ca72v

Butar-Butar, M. (2018). Peranan Model Problem Based Learning (PBL) pada Materi Limit Fungsi Aljabar Kelas XI SMA. Jurnal 
Pendidikan Tambusai. 4, 105-114.

Fahmi, S., Widyanesti, S.(2017). Pendampingan E-Learning dengan Moodle yang Dipadukan dengan Software Matematika Geogebra untuk Guru. Aksiologiya: Jurnal Pengabdian Kepada Masyarakat, 1(2), 135-141.

Fitria Khasanah. (2019). Pembelajaran Limit Fungsi Berbasis Android Aplikasi Math Expert. Proceeding of Biology Education, 3(1), 32-39. https://doi.org/10.21009/pbe.3-1.5

Muin, A., Ulfah. R, M. (2012). Meningkatkan Hasil Belajar Matematika Siswa dengan Pembelajaran Menggunakan Aplikasi Moodle. 7(1). https://doi.org/10.21831/pg.v7i1.2838

Nugroho, K. U. Z., Widada, W., \& Herawaty, D. (2019). Pemahaman Konsep Matematika melalui Media Youtube dengan Pendekatan Etnomatematika. Jurnal Pendidikan Matematika Raflesia, 04(01), 96-106.

Nugroho, S., Redjeki, T., \& Mulyani, S. (2014). Penerapan Metode Drill and Practice Dilengkapi Modul untuk Meningkatkan Keaktifan dan Prestasi Belajar pada Materi Pokok Hidrolisis Garam Kelas XI IPA 5 SMA Negeri 7 Surakarta Tahun Pelajaran 2012 / 2013. Jurnal Pendidikan Kimia Universitas Sebelas Maret, 3(4), 93-99.

Nur Aqilah Rozali, \& Noor Dayana Abd Halim. (2020). Kesan Pembelajaran Berasaskan Inquiry dengan Integrasi Video terhadap Pencapaian Pelajar dalam Pembelajaran Matematik. Innovative Teaching and Learning Journal, 3(2), 42-60.

Rifa'i, M., \& Nisa, R. (2019). Pengembangan E-Modul Kalkulus Berbasis Geogebra dengan Dukungan Website Moodle. Math Didactic, 5(3), 259-268.

Robiah, S. S. (2020). Analisis Kesulitan Siswa Kelas XII dalam Menyelesaikan Soal pada Materi Limit Fungsi. Equation, 3(1), 65-75.

Sianturi, R.B.R (2018). Penerapan Metode Drill dan Resitasi Sebagai Upaya Meningkatkan Hasil Belajar Matematika Materi Limit Fungsi pada Siswa Kelas X IPA-1 SMA Negeri 1 Long Ikis Tahun Pelajaran 2017/2018. Jurnal Mitra Guru 11(11), 45-55. https://doi.org/10.1063/1.4914609

Sukma, Y., \& Supriyono, A. (2019). Peningkatan Hasil Belajar Siswa Materi Limit Fungsi Aljabar Menggunakan Discovery Learning di SMAN 10 Palembang. Lentera Sriwijaya: Jurnal Ilmiah Pendidikan Matematika, 1(2), 13-24. https://doi.org/10.36706/jls.v1i2.10041

Triyono, T. (2018). Penelitian Tindakan Kelas: Apa dan Bagaimana Melaksanakannya? March. https://doi.org/10.13140/RG.2.2.26385.12649

Wahyuni, Anggraini, S. R. (2016). Hasil Belajar Siswa pada Materi Grafik Fungsi. Jurnal Elektronik Pendidikan Matematika Tadulako, 03(03), 247-261. 